\title{
PERENCANAAN KAPASITAS PRODUKSI DENGAN PENDEKATAN BIAYA MARJINAL PADA PABRIK TAHU "SBR" BENGKULU
}

\author{
Afifi Bachtiar \\ Program Studi manajemen Perusahaan \\ Fakultas Ekonomi Universitas Prof. Dr Hazairin, SH
}

\begin{abstract}
Production capacity planning with a marginal cost approach and marginal sales proceeds to get the maximum profit at Bengkulu's "SBR" factory. This study aims to find out what the marginal production capacity planning will be produced with the marginal cost approach at Bengkulu's "SBR" plant. This research method is to establish a direct relationship with the tuhu factory "SBR" Bengkulu. The method of analysis is qualitative and quantitative analysis. The variables analyzed in this study are capacity planning and marginal cost. The calculation results are known that the factory knows "SBR" produces marginal production of 120 packs, with the minimum marginal cost of Rp 156.25 occurring in the third quarter of 2012. When compared with production knew that in the fourth quarter of 2012, the factory knew that Bengkulu's "SBR" had a marginal production of 80 packs with a marginal cost of Rp. 2000, so it would be more profitable when marginal production was 120 packs. These results can be concluded that production capacity planning with a marginal cost approach will benefit the factory knowing "SBR" Bengkulu.
\end{abstract}

Keywords: Capacity planning and marginal costs.

\section{PENDAHULUAN}

Pada umumnya tujuan mendirikan usaha adalah untuk memperoleh laba, di samping itu juga untuk menjaga kelangsungan hidup usaha serta perkembangannya. Perusahaan yang memfokuskan pada penghasilan laba atau keuntungan sangat memerlukan suatu perencanaan yang baik sesuai dengan tujuan yang telah di tetapkan. Perencanaan merupakan faktor yang penting dalam proses pengambilan keputusan yang berhubungan dengan kegiatan operasional perusahaan. Kegiatan operasional perusahaan merupakan interaksi antara bahan dasar, bahan-bahan pembantu, tenaga kerja, dan mesin-mesin serta alat-alat perlengkapan yang dipergunakan. Dengan adanya interaksi antara faktor-faktor produksi tersebut maka akan keluarlah output atau hasil.

Bagian produksi perusahaan memegang peran penting dalam usaha mempengaruhi suatu organisasi. Bagian produksi sering dilihat sebagai salah satu fungsi manajemen yang menentukan penciptaan produk serta turut mempengaruhi peningkatan dan penurunan penjualan. Artinya produk yang di produksi harus selalu mengikuti standar pasar yang diinginkan, bukan diproduksi atas dasar mengejar target semata. Bidang produksi mempunyai lima tanggungjawab keputusan utama, yaitu proses, kapasitas, persediaan, tenaga kerja, mutu/kualitas. Fahmi, (2012:1).

Dengan tanpa adanya rencana kerja atau dengan adanya rencana kerja yang kurang baik maka tujuan tidak akan dapat dicapai dengan efektif dan efisien, sehingga 


\section{CREATIVE RESEARCH MANAGEMENT JOURNAL-CRMJ Juli}

faktor-faktor produksi yang ada akan dipergunakan secara boros. Gitosudarmo, (2007:61). Faktor-faktor produksi dibedakan kepada empat golongan yaitu, tenaga kerja, tanah, modal, dan keahlian keusahawan.

Dalam menentukan komposisi faktor produksi yang akan meminimumkan biaya produksi, produsen, perlu memperhatikan, beasarnya pembayaran kepada faktor produksi tambahan yang akan digunakan, dan besarnya pertambahan hasil penjualan yang diwujudkan oleh faktor produksi yang ditambah tersebut. Sukirno, (2009:193). Dalam tiap proses produksi diperlukan beberapa pertimbangan yang matang menyangkut batas maksimal kerja dari satu alat dan mesin serta tenaga kerja yang digunakan dalam proses produksi berlangsung. Hal ini menjadi suatu yang penting untuk melihat sejauh mana alat-alat produksi mampu beroprasi. Jika dalam menjalankan fungsinya, alat tersebut dipaksakan, maka tidak menutup kemungkinan terjadi over load, sehingga hal tersebut dapat menyebabkan alat tersebut rusak. Dengan demikian akan terjadi pembengkakan biaya produksi. Dari gambaran tersebut terlihat bahwa perencanaan kapasitas produksi menjadi begitu penting. Perencanaan kapasitas adalah suatu proses sistematis untuk menentukan tingkat kapasitas yang optimal atas dasar permintaan pasar yang diperkirakan.

Jika permintaan pasar naik, perusahaan justru cenderung meningkatkan jumlah produksi untuk memenuhi kebutuhan konsumen. Apabila permintaan pasar tidak terpenuhi, maka perushaan akan mengalami kerugian, karena peluang yang ada di pasar tersebut akan di ambil oleh perusahaan lain yang sejenis. Untuk memenuhi permintaan pasar, perusahaan hendaknya mengadakan produksi marjinal yaitu produksi tambahan, sehingga jumlah produksi akan meningkat dan dapat memenuhi permintaan pasar, akan tetapi dengan adanya produksi marjinal, maka akan timbul juga biaya marjinal. Biaya marjinal adalah kenaikan biaya produksi yang dikeluarkan untuk menambah produksi sebanyak satu unit. Diharapkan dengan adanya produksi marjinal maka perusahaan akan mendapatkan keuntungan yang melebihi dari produksi standar. Akan tetapi tidaklah berarti bahwa setiap perusahaan akan selalu mendapatkan keuntungan dalam kegiatannya. Perusahaan akan memdapatkan keuntungan apabila harga jual lebih besar dari biaya produksi yang di keluarkan.

Hal inilah yang terjadi pada pabrik tahu "SBR" Bengkulu, dilihat dari data produksi pada tahun-tahun sebelumnya bahwa permintaan tahu di pasar semakin meningkat. Pabrik tahu "SBR" Bengkulu untuk saat ini memproduksi tahu dengan menghabiskan kacang kedelai sebanyak 500kg/hari. Pada awal berdiri pada tahun 2005, pabrik tahu "SBR" Bengkulu hanya memproduksi tahu dengan menghabiskan kacang kedelai $100 \mathrm{~kg} /$ hari, setiap tahunnya pabrik tahu "SBR" Bengkulu terus meningkatkan kapasitas produksinya, akan tetapi hal tersebut belum dapat sepenuhnya memenuhi permintaan pasar. Untuk memenuhi permintaan pasar tersebut, maka pimpinan pabrik tahu "SBR" Bengkulu diharapkan untuk mengadakan produksi marjinal, meskipun dengan produksi marjinal belum tentu pabrik tahu "SBR" Bengkulu akan mendapatkan keuntungan yang maksimum, karena tidak semua kegiatan suatu perusahaan akan selalu mendapatkan keuntungan. 


\section{TINJAUAN PUSTAKA}

\section{Pengertian Manajemen Operasional}

Menurut Handoko (2003;3) manajemen adalah Proses perencanaan, pengorganisasian, pengarahan dan pengawasan usaha-usaha para anggota organisasi dan penggunaan sumber daya-sumber daya organisasi lainnya agar mencapai tujuan organisasi yang telah ditetapkan. Pengertian manajemen menurut Hasibuan $(2006 ; 2)$ adalah: "Ilmu dan seni mengatur proses pemanfaatan sumber daya manusia dan sumbersumber lainnya secara efektif dan efisien untuk mencapai suatu tujuan tertentu."

Operasional berasal dari kata operasi yang mempunyai arti menurut Subagyo (2000:1) ialah "kegiatan untuk mengubah bentuk untuk menambah manfaat atau menciptakan manfaat baru dari suatu barang atau jasa." Sedangkan pengertian manajemen operasional menurut Daft ( 2006 : 216) adalah "Bidang manajemen yang mengkhususkan pada produksi barang, serta menggunakan alat-alat dan tekhnik-tekhnik khusus untuk memecahkan masalah-masalah produksi."

\section{Pengertian perencanaan}

Seigel dan Shim, dalam Fahmi, (2012:9) mendefinisiskan perencanaan adalah pemilihan tujuan jangka pendek dan jangka panjang serta merencanakan taktik dan strategi untuk mencapai tujuan tersebut. Menurut Gitosudarmo, (2007:61) perencanaan merupakan penentuan tujuan pokok (tujuan utama) organisasi beserta cara-cara untuk mencapai tujuan tersebut. Jadi rencancana kerja tidak lain adalah merupakan penetapan tujuan yang akan dicapai dan pemilihan usaha-usaha yang dapat dilaksanakan untuk mencapai tujuan tersebut. Dalam hal ini perencanaan mengandung pengertian sebagai berikut: Penentuan tujuan tentang keadaan masa depan yang diinginkan, Pemilihan dan penentuan cara yang akan ditempuh (dari semua alternatif yang mungkin) dan Usaha mencapai tujuan tersebut.

Perencanaan adalah suatu proses pemilihan dan pemikiran yang menghubungkan fakta-fakta berdasarkan asumsi-asumsi yang berkaitan dengan masa datang dengan menggambarkan dan merumuskan kegiatan-kegiatan tertentu yang diyakini diperlukan untuk mencapai tujuan-tujuan tertentu dan menguraikan bagaimana pencapaiannya.

\section{Tujuan Perencanaan dan Pengendalian}

Tujuan dari pembuatan perencanaan dan pengendalian, yaitu:

a. Suatu perencanaan dan pengendalian disusun serta dikonsep dengan tujuan untuk memperkecil risiko yang akan terjadi di kemudian hari, termasuk meminimalisir berbagai biaya yang dianggap tidak efisien yang mungkin timbul selama pekerjaan berlangsung.

b. Suatu perencanaan dan pengendalian yang dibuat harus didasarkan atas konsep target-target atau prioritas-prioritas yang ingin dibangun. Ini sebagaimana ditegaskan aleh Ross, dkk dalam Fahmi, (2012:15) bahwa " mungkin hasil yang paling penting dari proses perencanaan adalah bahwa proses itu memaksa para manajer memikikan sasaran dan membuat prioritas."

c. Suatu perencanaan dan pengendalian yang dikonsep secara baik serta dijalankan dengan benar mampu memberi keyakinan kepada para stakeholders' perusahaan. 
d. Suatu perencanaan dan pengendalian yang baik mampu memberikan kekuatan deteksi kepada berbagai peristiwa yang terjadi, dimana peristiwa tersebut dirasakan berbeda dari biasanya, dan akhirnya konsep pencegahan dapat diterapkan. (Fahmi, 2012:14-15)

Menurut Kusuma (2004:1) tujuan dari perencanaan dan pengendalian produksi adalah merencanakan dan mengendalikan aliran material ke dalam, di dalam, dan keluar pabrik sehingga posisi keuntungan optimal yang merupakan tujuan perusahaan dapat dicapi.

\section{Defenisi dan Fungsi Perencanaan/Pengendalian Produksi dalam Aktivitas Produksi}

Produksi adalah Sesutu yang dihasilkan oleh suatu perusahaan baik berbentuk barang (goods) maupun jasa (service) dalam suatu periode waktu yang selanjutnya dihitung sebagai nilai tambah bagi perusahaan. Bentuk hasil produksi dengan katagori barang (goods) dan jasa (service) sangat tergantung pada katagori aktivitas bisnis yang dimiliki perusahaan yang bersangkutan. Fahmi (2012:2). Selanjutnya menurut Alma, dalam Fahmi,(2012:2), pengertian produksi dapat ditinjau dari dua sudut, yaitu: Pengertian produksi dalam arti sempit, yaitu mengubah bentuk barang menjadi barang baru, ini menimbulkan form unility. barang dan jasa. Prishardoyo (2005). Pengertian produksi dalam arti luas, yaitu usaha yang menimbulkan kegunaan karena place, time, dan possession. Produksi merupakan kegiatan yang dilakukan untuk memenuhi kebutuhanmanusia dengan menghasilkan barang atau meningkatkan nilai guna suatu (dalam carapedia.com/pengertian_definisi_produksi_info2348.

Pada dasarnya fungsi dasar yang harus dipenuhi oleh aktivitasperencanaan dan pengendalian produksi adalah meramalkan permintaan produk yang dinyatakan dalam jumlah produk sebagai fungsi dari waktu yaitu :

1. Menetapkan jumlah dan saat pemesan bahan baku serta komponen secara ekonomis dan terpadu

2. Menetapkan keseimbangan antara tingkat kebutuhan produksi, teknik pemenuhan pesanan, serta memonitor tingkat persediaan produk jadi setiap saat, membandingkannya dengan rencana persediaan, dan melakuakan revisi atas rencana produksi pada saat yang ditentukan; serta

3. Membuat jadwal produksi, penugasan, pembebanan mesin dan tenaga kerja yang terperinci sesuai dengan ketersediaan kapasitas dan fluktuasi permintaan pada suatu periode. Kusuma (2004:2).

\section{Langkah-Langkah dalam Perencanaan Produksi dan Operasi}

Langkah-langkah pokok dalam membuat suatu rencana adalah sebagai berikut:

a. Menentukan tujuan yang akan dicapai. Tujuan tersebut harus memiliki 3 syarat yaitu jelas, mungkin dicapai dan tidak terlalu ringan

b. Menentukan kedudukan perusahaan dalam kaitannya dengan tujuan yang hendak dicapai. Hal ini juga dapa berarti menentukan tujuan-tujuan antara subtujuan yang akan menopang pencapaian tujuan utama tersebut. 


\section{CREATIVE RESEARCH MANAGEMENT JOURNAL-CRMJ Juli}

c. Menentukan faktor-faktor yang mendukung dan yang menghambat tercapainya tujuan tersebut.

d. Merumuskan kegiatan yang harus dilaksanakan guna memperoleh perencanaan yang efektif harusla dipastikan bahwa keengganan dalam merumuskan tujuan dapat dihindari. Gitosudarmo, (2007:63-64)

Perencanaan kapasitas adalah proses penentuan tenaga kerja, mesin, dan fasilitas fisik lainnya yang diperlukan untuk mencapai sasaran keluaran tertentu. (markbiz.files.wordpress.com/2008/06/3-perencanaan-kapasitas.pdf)

Kapasitas didefinisikan sebagai jumlah output (produk) maksimum yang dapat dihasilkan suatu fasilitas produksi dalam suatu selang waktu tertentu. Pengertian ini harus dilihat dari tiga perspektif agar lebih jelas, yaitu:

a. Kapasitas desain: menunjukaan output maksimum pada kondisi ideal dimana tidak terdapat konflik penjadwalan, tidak ada produk yang rusak atau cacat, perawatan hanya yang rutin, dsb.

b. Kapasitas efektif: menunjukan output maksimum pada tingkat oprasi tertentu. Pada umumnya kapasitas efektif lebih rendah dari pada kapasitas desain.

c. Kapasitas aktual: menunjukan output nyata yang dapat dihasilkan oleh fasilitas produksi. Kapasitas actual sedapat mungkin harus diusahakan sama dengan kapasitas efektif.

Dalam kaitannya dengan definisi di atas maka perencanaan kapasitas berusaha untuk mengintegrasikan faktor-faktor produksi untuk meminimasi ongkos fasilitas produksi. Dengan kata lain, keputusan-keputusan yang menyangkut kapasitas produksi harus mempertimbangkan fakto-faktor ekonomi fasilitas produksi tersebut, termasuk di dalamnya efisiensi dan utilisasinya. Adapun faktor-faktor yang mempengaruhi pembentukan kapasitas efektip ialah rancangan produk, kualitas bahan yang digunakan, sikap dan motivasi tenaga kerja, perawatan mesin/fasilitas, serta rancangan pekerjaan. Kusuma (2004:112).

Kapasitas produksi dapat didefinisikan sebagai volume atau jumlah produk yang dapat dihasilkan oleh fasilitas produksi atau perusahaan dalam periode tertentu dengan menggunakan sumber daya yang tersedia saat itu. Kusuma (2004:112). Kapasitas produksi adalah tingkat aktivitas maksimum yang dapat dicapai dengan struktur produksi yang diberikan.

\section{Biaya Produksi dan Biaya Majinal}

Biaya produksi dapat didefinisikan sebagai semua pengeluaran yang dilakukan oleh perusahaan untuk memproleh faktor-faktor produksi dan bahan-bahan mentah yang digunakan untuk menciptakan barang-barang yang diproduksikan perusahaan tersebut. Sukirno, (2009:208)

Jenis-jenis biaya produksi:

1. Fixed cost adalah biaya yang tetap yang harus dikeluarkan oleh perusahaan selama perusahaan tersebut terus menjalankan aktivitasnya. Contohnya biaya asuransi, biaya pajak, biaya sewah, dan biaya-biaya lainnya. 
2. Variable cost merupakan biaya yang jumlahnya berubah sesuai dengan perubahan aktivitas. Contohnya pembelian bahan baku.

3. Total cost atau biaya total menurut Kalangi dalam fahmi adalah terdiri dari dua jenis biaya dalam proses produksi, yakni biaya tetap total dan biaya variable total. Fahmi, (2012:69-73)

Biaya marjinal adalah marginal cost yaitu peningkatan atau penurunan total biaya suatu pakibat perusahaan akibat penambahan atau pengurangan satu unit keluaran; penentuan biaya marjinal sangat penting dalam menentukan jumlah; biasanya, biaya marjinal menurun sejalan dengan meningkatnya volume produksi sesuai dengan skala ekonomi, termasuk faktor potongan harga / diskon biaya material, tenaga kerja / pekerja terlatih, dan penggunaan mesin yang lebih efisien.(http://www.mediabpr.com/kamusbisnis bank/biaya_marginal.aspx). Biaya marjinal (marginal costs), adalah biaya dimana produksi harus sama dengan penghasilan marjinal jika ingin memaksimalkan laba.Biaya kesempatan (opportunity costs), merupakan pendapatan atau penghematan biaya yang dikorbankan sebagai akibat dipilihnya alternatif tertentu (http://otakrote.blogspot.com/2011/10/konsep-konsep-biaya-dalam-pengambilan.html)

Biaya marjinal (Incremental or Marginal Cost) adalah perubahan biaya berkaitan dengan perubahan satu unit output. Sedangkan, biaya inkremental dapat diartikan sebagai tambahan biaya total dari penerapan keputusan manajerial. (http://anggitsetiyadi87.blogspot.com/2011/10/macam-macam-biaya.html). Menurut sukirno (2009:238) biaya marjinal yaitu tambahan biaya yang perlu di keluarkan untuk menambah satu unit produksi.

\section{Kerangka Pemikiran}

\section{GAMBAR I \\ KERANGKA PEMIKIRAN}

\begin{tabular}{|c|}
$\begin{array}{c}\text { Perencanaan } \\
\text { Kapasitas } \\
\text { Produksi }\end{array}$ \\
$\begin{array}{c}\text { Biaya } \\
\text { Marjinal }\end{array}$ \\
\hline
\end{tabular}

\section{HASIL DAN PEMBAHASAN}

\section{Gambaran Umum perusahaan}

Pabrik tahu "SBR" Bengkulu merupakan perusahaan kecil yang memproduksi tahu. Pabrik tahu "SBR" Bengkulu berada di Jalan Kemang Manis IV Rt 7 Rw 2 No 48 sawah lebar kota Bengkulu. Pabrik tahu "SBR" Bengkulu didirikan pada tahun 2005. Pada awal berdirinya pabrik tahu "SBR" Bengkulu hanya memiliki karyawan sebanyak 4 orang untuk memproduksi tahu sebanyak 320 bungkus (100 kg kacang kedelai) per hari. Pada saat ini pabrik tahu "SBR" Bengkulu sudah memiliki karyawan sebanyak 8 orang dan mampu memproduksi tahu dengan menghabiskan kacang kedelai sebanyak $300 \mathrm{~kg} \mathrm{~s} / \mathrm{d} 500 \mathrm{~kg}$ per hari (960 bungkus s/d 1600 bungkus). Sistem penjualan yang dilakukan oleh pabrik tahu "SBR" Bengkulu pada awal berdiri adalah langsung menjual 
dipasar dengan membuka kedai sendiri dan mengantar tahu yang sudah di pesan oleh pelanggan ke alamat pelanggan. Sedangkan sistem pemasaran saat ini, pabrik tahu "SBR" Bengkulu tidak lagi membuka kedai untuk menjual tahu hasil produksinya, melainkan hanya mengantar tahu sesuai pesanan ke alamat pelanggan. Hal ini dilakukan karena semakin banyaknya pelanggan yang memesan tahu hasil produksi pabrik tahu "SBR" Bengkulu.

Bahan baku pada usaha pabrik tahu "SBR" Bengkulu ini adalah biji kacang kedelai. Hal yang harus di perhatikan pada bahan baku agar hasil produksi berkualitas baik adalah pemilihan biji kacang kedelai dengan kualitas bagus ( biji besar dan tidak digerogoti ulat). Pada proses ini bisa dilakukan dengan menggunakan tampi/tampah agar lebih mudah. Bahan penolong dalam proses produksi tahu adalah asam cuka atau batu tahu (kalsium sulfat atau CaSO4) yang dicampurkan ke dalam air hasil saringan kedelai agar air saringan tersebut menggumpal. Proses Produksi Ada beberapa tahapan proses produksi tahu :

1. Hal pertama yang harus kita lakukan adalah memilih kedelai dengan kualitas bagus (biji besar dan tidak digerogoti ulat). Pada proses ini kita bisa menggunakan Tampi/tampah agar lebih mudah.

2. Setelah kita mendapatkan kedelai yang super, kemudian dicuci, kemudian direndam dalam air kurang lebih selama 6 jam.

3. Setelah proses perendaman selesai, kedelai dicuci dengan air bersih sampai benarbenar bersih. Hal ini bertujuan agar kebersihan kedelai terjamin.

4. Langkah berikutnya kedelai hancurkan menggunakan mesin pemecah kedelai.

5. Pada proses kelima, kedelai yang sudah hancur tersebut digiling sampai halus(lembut) menggunakan mesin giling kedelai. Pada proses ini akan dihasilkan santan kedelai hasil penggilingan kedelai tadi.

6. Santan kedelai yang dihasilkan pada proses ke 5 langsung direbus dengan menggunakan wajan sampai mendidih.

7. Setelah itu santan kedelai dipindahkan dari wajan ke dalam bak yang telah kita siapkan sebelumnya. Kemudian saring dengan menggunakan kain belacu yang telah dibuat sedemikan rupa. Untuk mendapatkan hasil yang maksimal proses penyaringan ini harus dilakukan secara berulang-ulang.

8. Campur santan kedelai hasil penyaringan dengan asam cuka agar menggumpal. Selain dicampur dengan asam cuka, juga dapat menambahkan air kelapa atau bubuk/serbuk batu tahu (sulfat kapur).

9. Gumpalan hasil campuran santan kedelai yang sudah mulai mengendap itu dituangkan dalam cetakan tahu yang sebelumnya telah dialasi dengan menggunakan kain belacu.

10. Adonan tahu dalam cetakan dikempa/dipress selama kurang lebih 2 menit agar air yang terkandung di dalam adonan tahu tersebut dapat terperas habis tak tersisa.

11. Setelah itu adonan tahu tersebut sudah dapat dipotong-potong sesuai ukuran yang diinginkan

12. Dan tahupun sudah jadi dan siap untuk dipasarkan 


\section{Lay Out Pabrik Tahu "SBR" Bengkulu}

Penempatan peralatan produksi secara cermat akan mempelancar kegiatan proses produksi. Lay out fasilitas yang diperlukan merupakan keseluruhan bentuk dan penempatan fasilitas-fasilitas yang diperlukan dalam proses produksi. Di dalam berproduksi diperlukan peralatan-peralatan, perlengkapan, mesin-mesin atau fasilitas produksi sehingga hasil produksi dapat diproduksi dengan jumlah dan kualitas yang sesuai. Pada pabrik tahu "SBR" Bengkulu menggunakan lay out produk/garis dimana mesin-mesin dan perlengkapan disusun berdasarkan urutan operasi yang diperlukan bagi produk yang dibuat dikarenakan perusahaan ini hanya memproduksi satu macam produk secara terus-menerus. Gambar lay out pabrik tahu "SBR" Bengkulu diperlihatkan pada gambar berikut :

\section{GAMBAR II \\ LAY OUT PABRIK TAHU "SBR" BENGKULU}

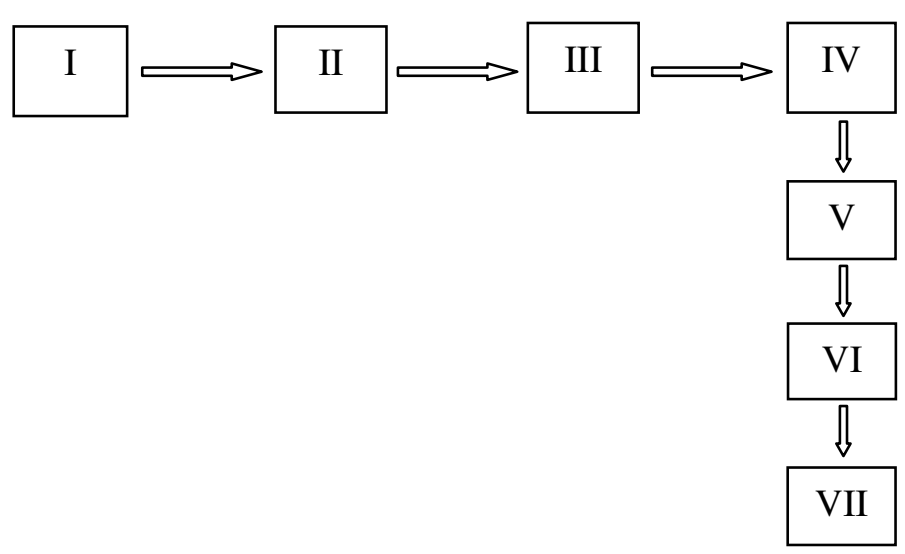

Keterangan :

I. Tempat penimbangan biji kacang kedelai

II. Tempat penbersihan biji kacang kedelai

III. Mesin pemecah

IV. Mesin penggiling

V. Tempat perebusan

VI. Tempat penyaringan

VII. Tempat pencetakan

\section{Pemasaran dan Kebijaksanaan produksi}

Pabrik tahu "SBR" Bengkulu memasarkan produknya hanya di pasar kota Bengkulu. Pabrik tahu "SBR" Bengkulu sudah memiliki mitra tersendiri di pasar dan sudah ada pelanggan penjual gorengan yang setiap hari memesan tahu kepada pabrik tahu "SBR" Bengkulu. Sistem pemasaran yang dilakukan oleh pabrik tahu "SBR" Bengkulu adalah mengantar langsung pesanan tahu ke alamat pelanggan. Ini dilakukan untuk memberikan pelayanan yang terbaik agar pelanggan merasa puas. 
Dalam menjalankan operasional perusahaan, kebijaksanaan produksi merupakan hal terpenting yang harus dilakukan oleh pemilik perusahaan agar tujuan perusahaan tercapai. Hal ini dapat dilihat dari bagaimana penentuan jumlah produksi, bagaimana penggunaan sumber daya dan bagaimana untuk mengantisipasi permintaaan. Pabrik tahu "SBR" Bengkulu menentukan jumlah produksi berdasarkan rata-rata permintaan konsumen dalam setiap harinya. Namun terkadang perusahaan tidak mampu memenuhi seluruh permintaan konsumen karena terbatasnya tenaga kerja. Jadi pabrik tahu "SBR" Bengkulu hanya mampu memproduksi tahu dengan menghabiskan kacang kedelai sebanyak 300kg s/d 500kg per hari dengan jumlah karyawan sebanyak 8 orang. Data penjualan tahu pada pabrik "SBR" Bengkulu diperlihatkan pada table I berikut ini :

TABEL I

DATA PRODUKSI PABRIK TAHU “SBR" BENGKULU TAHUN 2011-2012

\begin{tabular}{|l|l|l|l|l|}
\hline Tahun & & $\begin{array}{r}\text { Volume } \\
\text { produksi }\end{array}$ & (Bungkus) & \\
\hline & Triwulan I & Triwulan II & Triwulan III & Triwulan IV \\
\hline 2011 & 960 & 1040 & 1040 & 1120 \\
\hline 2012 & 1200 & 1280 & 1440 & 1520 \\
\hline
\end{tabular}

Sumber : data pabrik tahu "SBR" Bengkulu diolah

Jika digambarkan dalam bentuk grafik, maka data penjualan pabrik tahu "SBR" Bengkulu pada tahun 2011-2012 dapat digambarkan seperti gambar III berikut :

GAMBAR III

GRAFIK PRODUKSI TAHU PADA PABRIK TAHU “SBR” BENGKULU TAHUN2011-2012

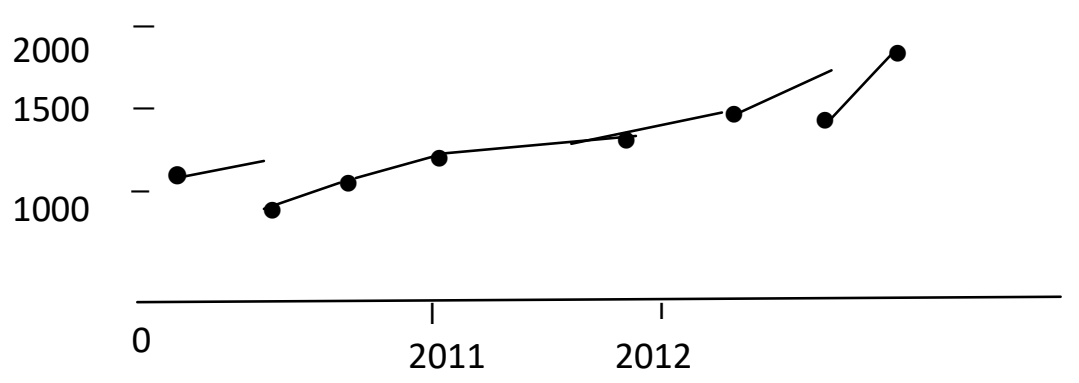

Produksi tahu pada pabrik tahu "SBR" Bengkulu mengalami fluktuasi penjualan. Tetapi secara keseluruhan menunjukan peningkatan produksi pada tahun berikutnya. Jika dilihat dari grafik di atas, terjadi peningkatan produksi yang paling tajam pada triwulan III tahun 2012 yaitu menjadi 1440 bungkus dibandingkan dengan triwulan II tahun 2012 yang hanya menunjukkan angka 1280 bungkus. Hal ini disebabkan karena banyaknya masyarakat yang membuka usaha dengan menggunakan 


\section{CREATIVE RESEARCH MANAGEMENT JOURNAL-CRMJ Juli}

bahan baku tahu, seperti penjual gorengan, penjual kuch-kuch ho tahu, pedagang sayur keliling dan mitra usaha dipasar tradisional.

\section{Pembahasan}

Tujuan sebuah perencanaan adalah mengusahakan agar barang jadi hasil proses produksi itu sesuai dengan kebutuhan konsumen baik dalam jumlah dan waktu, dan tentu saja tetap memperhatikan kualitas dan harga. Perencanaan juga memiliki peranan penting dalam kegiatan perusahaan yang berguna untuk dapat memperkirakan kebutuhan-kebutuhan masa datang dan juga mengetahui apa yang harus dilakukan untuk masa yang akan datang pada perusahaan tersebut. Perencanaan yang dibahas dalam penelitian ini adalah perencanaan produksi marjinal untuk mengetahui jumlah biaya marjinal yang akan dikeluarkan

\section{Analisa kuantitatif a.Perhitungan Biaya Produksi}

\section{TABEL II}

\section{JUMLAH PRODUKSI DAN BIAYA PRODUKSI}

\begin{tabular}{|c|c|c|c|c|}
\hline $\begin{array}{c}\text { Jumlah } \\
\text { produksi }\end{array}$ & $\begin{array}{c}\text { Biaya } \\
\text { Tetap }\end{array}$ & $\begin{array}{c}\text { Biaya } \\
\text { Berubah }\end{array}$ & $\begin{array}{c}\text { Biaya } \\
\text { Total }\end{array}$ & $\begin{array}{c}\text { Biaya } \\
\text { Marjinal }\end{array}$ \\
\hline 960 & 500.000 & 500.000 & 1.000 .000 & 520,83 \\
\hline 1040 & 500.000 & 550.000 & 1.050 .000 & 625 \\
\hline 1040 & 500.000 & 580.000 & 1.080 .000 & - \\
\hline 1120 & 500.000 & 620.000 & 1.120 .000 & 500 \\
\hline 1200 & 500.000 & 660.000 & 1.160 .000 & 500 \\
\hline 1280 & 500.000 & 675.000 & 1.175 .000 & 187,5 \\
\hline 1440 & 500.000 & 700.000 & 1.200 .000 & 156,25 \\
\hline 1520 & 500.000 & 860.000 & 1.360 .000 & 2000 \\
\hline
\end{tabular}

Sumber : data pabrik tahu "SBR" Bengkulu diolah

Keterangan :

1. Dalam kolom (1) menunjukuan jumlah produksi yang dapat dicapai

2. Kolom (2) menggambarkan biaya tatap total yaitu biaya yang dikeluarkan untuk memperoleh faktor produksi (input) yang tidak dapat diubah nilainya yang digunakan dalam proses produksi. Misalnya membeli mesin dan mendirikan bangunan

3. Kolom (3) biaya berubah total yaitu semua biaya yang dibelanjakan untuk membeli input berubah. Misalnya tenaga kerja dan membeli bahan baku.

4. Kolom (4) menunjukan biaya total yaitu biaya yang diperoleh dengan memjumlahkan biaya tetap total dengan biaya berubah total. Biaya total dapat dicari dengan rumus : $\mathrm{TC}=\mathrm{TFC}+\mathrm{TVC}$. Dimana TFC adalah biaya tetap total, sedangkan TVC adalah biaya berubah total.

5. Kolom (5) menunjukan biaya marjinal yaitu tambahan biaya yang perlu dikeluarkan untuk menambah satu unit produksi. Biaya marjinal dapat dicari dengan rumus : 
$\mathrm{MC}_{\mathrm{n}}=\frac{\Delta T C}{\Delta Q}$

Keterangan :

$\mathrm{MC}_{\mathrm{n}}$ adalah biaya marjinal produksi ke-n

$\triangle \mathrm{TC}$ adalah pertambahan jumlah biaya total

$\Delta \mathrm{Q}$ adalah pertambahan jumlah produksi

\section{Analisa kualitatif}

Seperti diuraikan sebelumnya analisa kualitatif bersifat menjelaskan dan menggambarkan hasil-hasil penelitian yang tidak dapat diterangkan secara kuantitatif. Dilihat dari hasil produksi pabrik tahu "SBR" Bengkulu merupakan perusahaan yang memproduksi barang yang langsung dapat di konsumsi oleh konsumen.tentunya sangat perlu diperhatikan kebersihan, cita rasa yang tercakup dalam kualitas tahu agar konsumen tidak berpindah memilih produksi tahu yang lain. Berdasarkan hasil perhitungan yang telah dilakukan melalui analisa kuantitatif, diketahui bahwa pabrik tahu"SBR" Bengkulu akan mengeluarkan biaya marjinal paling kecil pada triwulan III tahun 2012 dengan jumlah produksi marjinal sebanyak 120 bungkus dan biaya marjinal sebesar Rp156,25.

\section{Kesimpulan}

Dari hasil penelitian yang telah di uraikan pada bab sebelumnya, dapat disimpulkan bahwa tidak semua kegiatan perusahaan akan mencapai hasil yang sesuai dengan tujuan yang telah di rencanakan. Dimana tujuan utama dari suatu perusahaan adalah mendapatkan keuntungan yang maksimum. Hasil penelitian yang telah di bahas pada bab sebelumnya, menunjukan bahwa pabrik tahu "SBR" Bengkulu akan memproduksi tahu dengan kapasitas yang telah ditentukan sebelumnya dengan biaya marjinal yang relative lebih kecil dari produksi-produksi yang telah dilaksanakan. Jumlah produksi marjinal yang akan di produksi adalah sebanyak 120 bungkus dengan biaya marjinal sebesar Rp156,25. Ini terjadi pada triwulan III tahun 2012. Dibandingkan dengan produksi marjinal pada tiwulan ke IV tahun 2012 sebanyak 80 bungkus dengan biaya marjinal sebesar Rp 2000.

\section{Saran}

Setelah penulis melakukan penelitian di pabrik tahu "SBR" Bengkulu, penulis dapat mengajukan saran sebagai berikut :

1. Diharapkan pada pabrik tahu "SBR"Bengkulu dapat membuat perencanaan yang baik untuk menentukan kapasitas produksi, agar dapat menghasilkan produk yang berkualitas tinggi.

2. Dalam rangka melakukan kegiatan operasional perusahaan, diharapkan agar pabrik tahu "SBR" Bengkulu manambah jumlah tenaga kerja, agar kegiatan operasional perusahaan dapat berjalan dengan baik. 


\section{DAFTAR PUSTAKA}

Daft,Richald L. 2006. Manajemen, Edisi 6. Jakarta: Salembah Empat

Fahmi, Irham. 2012. Manajemen Produksi dan Operasi. Bandung: Alfabeta.

Gitosudarmo, Indriyo. 2007. Manajemen Oprasi. Edisi 3. Yogyakarta: BPFE.

Handoko,T. Hani. 2003. Manajemen. Edisi 2.Yogyakarta: BPFE.

Hasibuan, Melayu.SP. 2006. Manajemen Dasar, Pengertian dan Masalah, Edisi Revisi. Jakarta: Bumi Aksara.

http://otak-rote.blogspot.com/2011/10/konsep-konsep-biaya-dalam-pengambilan.html, diakses 8 juli 2013.

http://anggitsetiyadi87.blogspot.com/2011/10/macam-macam-biaya.html, diakses 8 juli 2013

http://www.mediabpr.com/kamus-bisnis-bank/biaya_marginal.aspx. diakses 8 juli 2013 Kusumu, hendra. 2004. Perencanaan dan pengendalian produksi. Ed 3. Yogyakarta: ANDI.

Markbiz.files.wordpress.com/2008/06/3-perencanaan-kapasitas.pdf. diakses 8 juli 2013. Sokirno, sadono. 2009. Mikro Ekonomi: teori pengantar.Ed 3. Jakarta: Raja wali pres. Subagyo, Pangestu.2000. Manajemen Operasi. Edisi 1.Yogyakarta : BPFE Suprapto.j. 2000. Statistic: teori dan aplikasi. Ed 6. Cet 1. Jakarta: Erlangga 